\title{
Geotechnical Performance of Suction Caisson Installation in Multi-layered Seabed Profiles
}

\author{
M. Mehravar ${ }^{1 *}$, O. Harireche ${ }^{2}$, A. Faramarzi $^{3}$ \\ ${ }^{1}$ School of Engineering and Applied Science, Aston University, Birmingham, UK \\ ${ }^{2}$ Department of Civil Engineering, Faculty of engineering, University of Medina \\ ${ }^{3}$ Department of Civil Engineering, University of Birmingham, Birmingham, UK
}

Suction caissons consist of large cylindrical buckets made from steel. In order to serve as foundations for various offshore structures, suction caissons are pushed into the seabed under pressure differential exerted on their lid by an imposed suction. Despite their wide use in the oil and gas industry, there are still some uncertainties regarding their installation process as a result of changes in seabed profiles such as the existence of low permeability layers as well as the variation in soil properties with depth (e.g. permeability decreasing with depth due to an increase in soil density). It is known that seepage conditions play a pivotal role in the installation process, particularly in sand. Indeed, pressure gradients generated by the imposed suction inside the caisson cavity cause an overall reduction in the soil resistance around the caisson wall and at caisson tip, thereby assisting the penetration into the seabed. Successful installation of caisson foundations relies on accurate prediction of soil conditions, in particular soil shear resistance during the installation. Existing knowledge of the prediction of soil conditions and required suction during caisson installation has some limitations which often resulted into rather conservative design methods. Most design procedures used to control suction during caisson installation assume an isotropic and homogenous seabed profile. Moreover, the actual variation of pressure gradient around the caisson wall at different penetration depths is often ignored, although it significantly affects soil resistance. Natural seabed can possess a heterogeneous property where it may comprise of different layers of soils including the presence of layers with low-permeability i.e. clay or silt. In this paper, the effect of seepage on soil conditions during caisson installation is studied within the frame of the presence of a substratum that consists of silt. Suction induced seepage described throughout the installation process and its effects on frictional and tip resistance are considered. For this purpose, a numerical simulation is conducted on a normalised geometry of the suction caisson and surrounding soil, at different penetration depths. The distribution of pressure gradient on both inside and outside of the caisson wall is taken into consideration in both soil shear and tip resistance. Particular conclusions will be drawn on the implications of the presence of a low permeability silt layer on caisson installation.

\section{Introduction}

Suction caissons are large upturned bucket structures of cylindrical shape that are typically made from steel. These structures have recently been considered for foundations of offshore wind turbines (Byrne, et al., 2002). To install caissons, water will be extracted from the hollow space between the caisson lid and mudline (initial penetration into the seabed is achieved with caisson self-weight). In permeable soils such as sands, seepage occurs as 
a result of the applied suction which causes an overall reduction in soil resistance and facilitates caisson penetration (Tran, et al., 2007; Harireche, et al., 2014). The effect of seepage in installation has been well documented for soil profiles with a homogenous nature (Houlsby \& Byrne, 2005; Harireche, et al., 2013; Harireche, et al., 2014; Mehravar, et al., 2017). However, certain soil layer configurations, (e.g. the presence of a low-permeable layer), can have significant impact on the seepage mechanism and thereby the installation process. Nevertheless, design procedures in these particular situations have received less attention (Ibsen \& Thilsted, 2010). For instance, there are concerns when suction caissons are installed in sand underlain by a low permeability soil such as clay or silt. In such a soil profile the low permeability layer may create a hydraulic barrier in the soil and causes the installation to become very difficult if not impossible (Raines, et al., 2005). Few studies have considered suction caisson installation in multi-layered seabed profiles (Allersma, et al., 2001; Matusi, et al., 2002; Tran, et al., 2007; Cotter, 2009). It has generally been concluded that a larger suction is required compared to installations in homogeneous sand. In the above works, pressure gradients between seabed and caisson tip was used to predict the hydraulic gradient on both sides of the caisson wall (Houlsby \& Byrne, 2005; Cotter, 2009). Nevertheless, it has been proved that the variation of pressure gradient over the caisson penetration depth affects the whole installation process both in terms of reduction in soil resistance and critical condition for piping (Harireche, et al., 2014). Therefore, it is important to investigate the pressure gradient distribution over the penetration depth throughout the whole installation process. In this paper, a finite element procedure is implemented in an in-house finite element (FE) code and used to study the effect of the existence of a low permeability layer on suction caisson installation in sand. A parametric study is performed to investigate the effect of the depth of the low permeability layer on the reduction in soil resistance. The results are compared with those obtained from an installation in homogeneous sand and the difference will be highlighted and discussed.

\section{Formulation of the normalised seepage problem}

In this study the model problem of a suction caisson of radius $R$, and height $L$ is considered. Dimensions and values of pressure are normalised with respect to the caisson radius $(R)$ and magnitude of the applied suction respectively. The caisson penetration depth into the seabed and the depth of a silt layer (from the mudline) are denoted as $h$, and $h_{s}$ respectively. Therefore, the following normalized variables are adopted:

$$
p^{*}=\frac{p}{\bar{s}} \quad h^{*}=\frac{h}{R} \quad h_{s}^{*}=\frac{h_{s}}{R}
$$

Where $p^{*}, h^{*}$ and $h_{s}^{*}$ represent normalized excess pore water pressure, caisson penetration depth and depth of silt layer from the mudline, respectively. Figure 1, shows a vertical section of the soil-caisson system. A normalised

cylindrical system of coordinates $z^{*}=\frac{z}{R}$ and $r^{*}=\frac{r}{R}$ in the meridian plane is adopted where all dimensions were scaled with respect to the caisson radius. Due to the axisymmetric nature of the problem, only half of the caisson is modelled. In order to investigate the effect of the presence and the location of a silt layer on the caisson installation, four different soil profiles designated as Case A $\left(h_{s}^{*}=0\right), \mathrm{B}\left(h_{s}^{*}=3 h^{*}\right), \mathrm{C}\left(h_{s}^{*}=2 h^{*}\right)$ and D $\left(h_{s}^{*}=h^{*}\right)$ are considered. The soil profile in Case A corresponds to homogenous sand with permeability, $k_{\text {sand. The other }}$ three soil profiles (Case B, C and D) represent a sandy soil profile with a layer of silt that lies at different depths 
from the caisson tip. The caisson tip touches the top of the silt layer when the installation is complete in Case D $\left(h_{s}^{*}=h^{*}\right)$.

The permeability of the silt layer $\left(k_{\text {silt }}\right)$ in the multi-layered cases (Case B, C and D) is considered two order of magnitude lower than that of the sand layer (Tran, et al., 2007). The relevant sand and silt properties which are considered in this study have been selected based on the sand and silt sample properties used in the experimental tests conducted by (Tran, et al., 2007) . These properties are shown in Table 1.

Table 1: Soil properties

\begin{tabular}{|l|c|c|}
\hline Soil Property & Sand & Silt \\
\hline Permeability & $1.3 \times 10^{-4} \mathrm{~m} / \mathrm{s}$ & $1.3 \times 10^{-6} \mathrm{~m} / \mathrm{s}$ \\
\hline Saturated unit weight $\gamma \mathrm{sat}$ & $21 \mathrm{kN} / \mathrm{m}^{3}$ & $20 \mathrm{kN} / \mathrm{m}^{3}$ \\
\hline
\end{tabular}

The porewater seepage is described by Darcy's law: $\boldsymbol{u}=-k \nabla p$ where $\boldsymbol{u}$ is the porewater velocity, $k$ the permeability and $\nabla p$ represents the excess porewater pressure gradient. The normalized excess porewater pressure $p^{*}$ must satisfy equation 2 :

$$
\nabla^{* 2} p^{*} \equiv \frac{\partial^{2} p^{*}}{\partial r^{* 2}}+\frac{1}{r^{*}} \frac{\partial p^{*}}{\partial r^{*}}+\frac{\partial^{2} p^{*}}{\partial z^{* 2}}=0
$$

and the boundary conditions $p^{*}=-1$ on $\mathrm{OC}^{-}, p^{*}=0$ on $\mathrm{C}^{+} \mathrm{F}, \mathrm{FH}, \mathrm{BH}$ and $\frac{\partial p^{*}}{\partial r^{*}}=0$ on $\mathrm{CD}$ and $\mathrm{OB}$ (Figure 1).

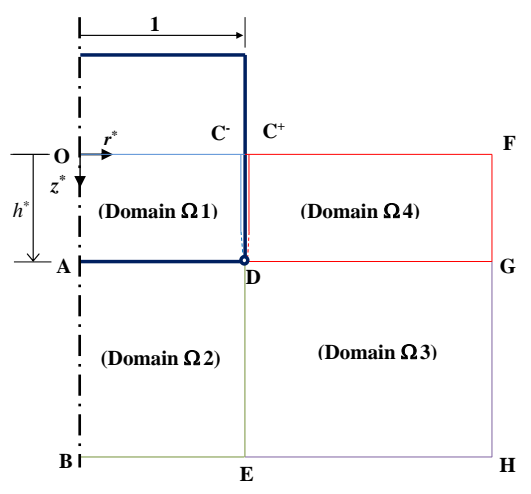

(a)

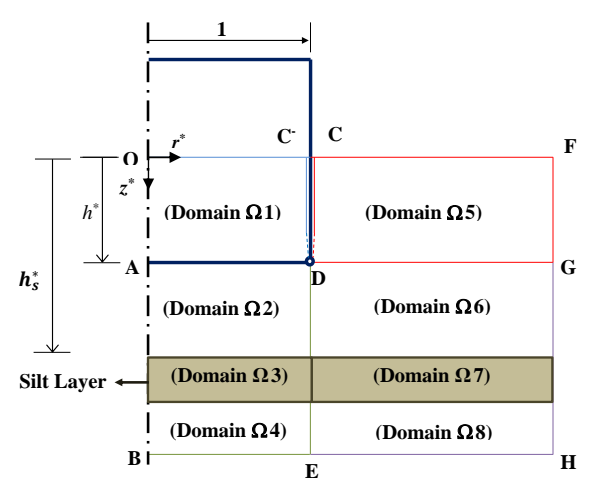

(b)

Figure 1: Normalized geometry; a) homogenous sand $\left(h_{s}^{*}=0\right)$, b) sand overlying a silt layer (zones $\Omega 3$ and $\Omega 7$ )

The finite element procedure has the advantages of taking into account soil loosening inside the caisson cavity $(\Omega 1)$ due to applied suction in a much more natural way compared to other numerical methods. The effect of soil loosening inside the caisson is not pronounced at the early stages of caisson penetration $\left(h^{*}<1\right)$. Therefore, a single permeability on both sides of the caisson wall is considered in this study. Of particular interest in this analysis, are the effects of the low permeability silt layer and its location, on soil resistance to caisson penetration. The scaled penetration depth has values: $h^{*}=0.2$ (typical of self-weight penetration), $h^{*}=0.4, h^{*}=0.6, h^{*}=$ 0.8 and $h^{*}=1$. 


\section{Effect of silt layer on the excess porewater pressure variation}

Generally, porewater seepage produced by suction causes a hydraulic gradient which on both sides of the caisson wall varies with depth. The contours of the normalised excess porewater pressure, $p^{*}$ for $h^{*}=1$ are shown in Figure 2. This figure corresponds to homogenous sand (Figure 2a), sand with a silt layer located at a depth, $h_{s}^{*}=$ $2 h^{*}$ (Figure 2b) and a sandy soil profile with a silt layer at $h_{s}^{*}=h^{*}$ (Figure 2c). These figures clearly indicate that the contours of excess porewater pressure have been affected due the presence of a layer of silt and this consequently has an impact on soil resistance to caisson penetration.

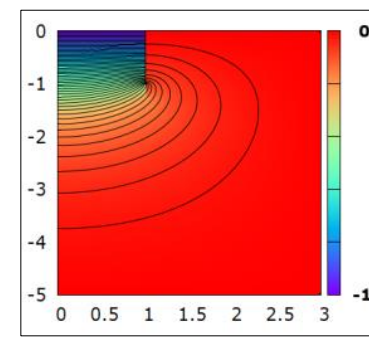

(a)

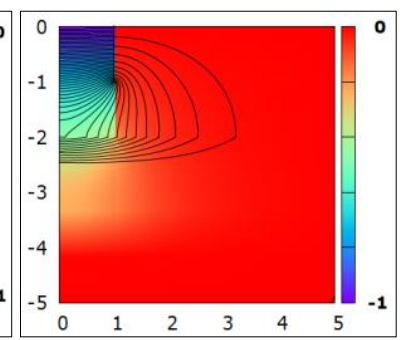

(b)

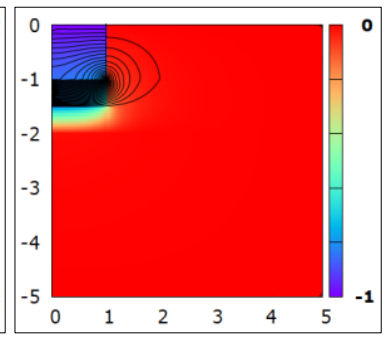

(c)

Figure 2 (a-c): Excess porewater pressure $p^{*}$ distribution for normalized penetration depth $h^{*}=1$ at (a) $h_{s}^{*}=0$ (homogenous sand), (b) $h_{s}^{*}=2 h^{*}$, (c) $h_{s}^{*}=h^{*}$.

The vertical component of the normalized hydraulic gradient $\left(g^{*}=\partial p^{*} / \partial z^{*}\right)$ on both sides of the caisson wall is represented as a function of the normalized penetration depth, $z^{*}$ and shown in Figure 3 (a-d). It should be noted that the vertical component of the pressure gradient on the inner and outer side of the caisson wall are given by $g_{i}(R, \xi)$ and $g_{o}(R, \xi)$, respectively. Two values of scaled penetration depth, namely: $h^{*}=0.4$ and 0.8 have been considered in conjunction with four different seabed profiles defined by $h_{s}^{*}=0,3 h^{*}, 2 h^{*} a n d h^{*}$ are considered. By comparing the normalized pressure gradient on both sides of the caisson wall (Figure 3a-d), It can be seen that:

- Regardless of soil seabed profile, pressure gradient at both sides of the caisson wall is higher at shallow penetration depths and the maximum pressure gradient occurs at the caisson tip. The effect of a low permeability silt layer is more noticeable inside the caisson cavity and becomes more pronounced when the caisson tip touches the silt layer $\left(h_{s}^{*}=h^{*}\right)$.

- $\quad$ There is no significant difference in the gradient magnitude for the first three soil profiles (Case A to C) on both sides of the caisson wall. However, such a difference becomes more noticeable once the caisson tip reaches the silt layer (Case D), and can affect the soil resistance through the increase in soil effective stress.

\section{Effect of silt layer on soil resistance to caisson penetration in layered soil}

In this study, the effect of the presence and location of a silt layer in a sandy soil profile on the soil resistance to caisson penetration is studied. For this aim, the reduction in frictional forces acting on the caisson wall and soil resistance at the caisson tip, due to applied suction, are calculated. Under seepage conditions produced by an 
applied suction, the lateral effective stress $\left(\sigma_{h}^{\prime}\right)$ acting on both sides of the caisson wall at a depth $\mathrm{z}$, is respectively given by:

$$
\begin{aligned}
& \dot{\sigma}_{h i}(R, z)=K\left(\gamma^{\prime} z-\int_{0}^{z} g_{i}(R, \zeta) d \zeta+\tilde{\sigma}_{i}(R, z)\right) \\
& \dot{\sigma}_{h o}(R, z)=K\left(\gamma^{\prime} z-\int_{0}^{z} g_{o}(R, \zeta) d \zeta+\tilde{\sigma}_{o}(R, z)\right)
\end{aligned}
$$

where the indices $i$ and $o$ indicate the regions inside and outside the caisson, respectively. The parameter $K$ denotes the coefficient of lateral earth pressure, $\gamma^{\prime}$ is the effective unit weight of the soil, $\tilde{\sigma}$ is the enhanced effective stress due to the effect of shear resistance which develops on the soil-caisson interface and $g_{i}(R, \xi)$ and $g_{o}(R, \xi)$ represent the vertical components of the pressure gradient on the inner and outer side of the caisson wall, respectively.

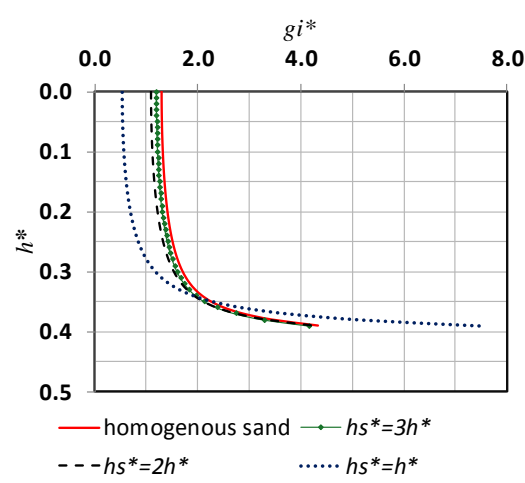

(a)

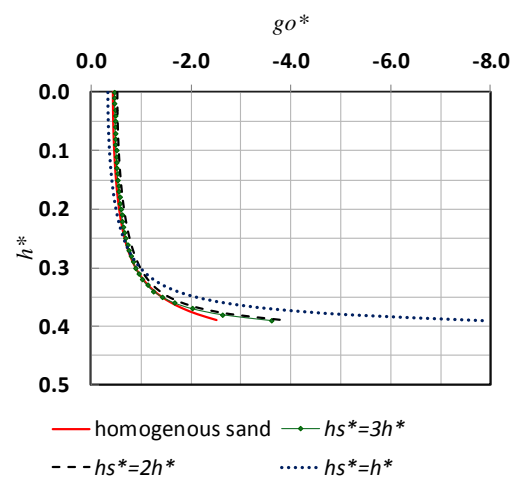

(b)

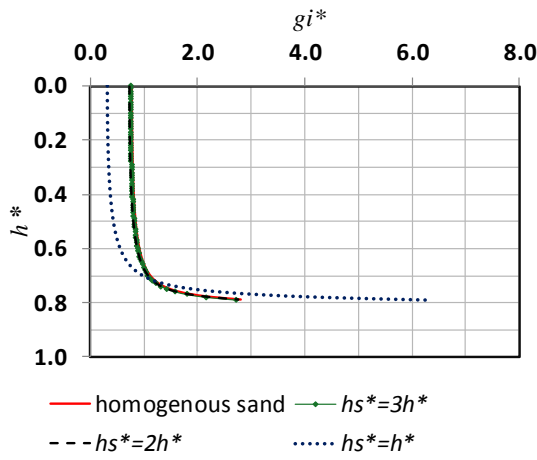

(c)

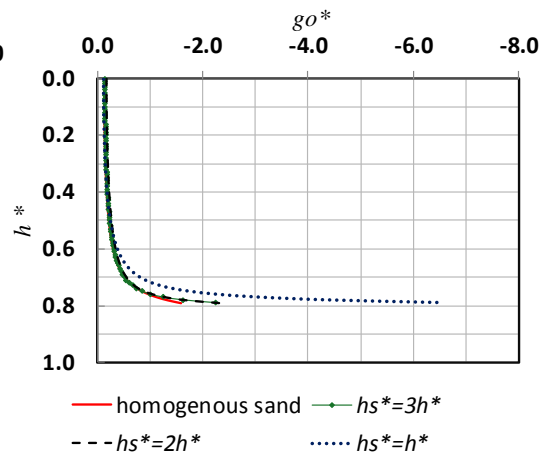

(d)

Figure 3(a-d): Dimensionless pressure gradient as a function of normalized depth for $\boldsymbol{h}^{*}=0.4$ and 0.8 , and four different soil seabed profiles

Seepage causes an overall reduction $\left(\Delta F_{S}\right)$ in the magnitude of the shear force acting on the caisson wall. This reduction $\left(\Delta F_{s}\right)$ can be expressed as a function of the normalized penetration depth $h^{*}$ as follows:

$$
\begin{aligned}
& \frac{\Delta F_{s}}{2 \pi R^{2} K \bar{s} \tan \delta}=\int_{0}^{h^{*}}\left[L_{i}^{*}\left(z^{*}\right)+L_{o}^{*}\left(z^{*}\right)\right] d z^{*} \\
& \Delta F_{s}^{*}=\frac{\Delta F_{s}}{\left(2 \pi R^{2} K \bar{s} \tan \delta\right)}
\end{aligned}
$$

where

$$
L_{i}^{*}\left(z^{*}\right) \equiv \int_{0}^{z^{*}} g_{i}^{*}\left(1, \zeta^{*}\right) d \zeta^{*}>0, L_{o}^{*}\left(z^{*}\right) \equiv \int_{0}^{z^{*}} g_{o}^{*}\left(1, \zeta^{*}\right) d \zeta^{*}<0
$$


and $\delta$ denotes the angle of friction at the interface soil-caisson and the suction magnitude at the mudline inside the caisson cavity is denoted by $\bar{s}$. The normalised reduction in frictional soil resistance, $\left(\Delta F_{S}^{*}\right)$ is calculated for all soil profiles (Case A to D) using the results of the FE model and Equations (5-7). In addition, the vertical effective stress at the caisson tip is reduced due to the applied suction, leading to further reduction in the total resisting force. Assuming the enhanced vertical stress at the caisson tip not affected by seepage, the reduction of resisting force at the caisson tip can be calculated by the following equation (Harireche, et al., 2014):

$$
\Delta F_{t}^{*}=\frac{\Delta F_{t}}{2 \pi R t N_{q} \bar{s}}=\frac{1}{2}\left(L_{i}^{*}\left(h^{*}\right)+L_{o}^{*}\left(h^{*}\right)\right)
$$

Figure 4 shows that in all four soil profile cases, the reduction in both shear and tip resistance forces increases during caisson penetration. This clearly shows that the location of the silt layer plays an important role in the reduction of the overall soil resistance to caisson penetration. The effects of the presence of a low permeability layer are particularly more considerable when the caisson tip gets closer to the silt interface. In other words, the difference in the reduction in soil resistance for the first three soil profiles (i.e. cases A to C) is not considerable. The soil profiles with silt layer located around the caisson tip, correspond to less reduction, and this is more pronounced in case D where the caisson tip is closer to the silt interface (Figure 4a and 4b)). It can be observed that, the reduction of shear and tip soil resistance in homogenous sand (Case A) is approximately 2.7 times higher than in case D. As a result, caisson installation in multi-layered seabed profiles, in the vicinity of a silt layer (e.g. Case D), requires a suction magnitude about 2.7 times higher than in homogenous sand (e.g. case A).

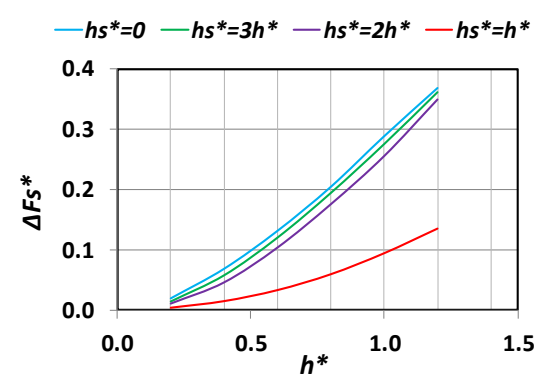

(a)

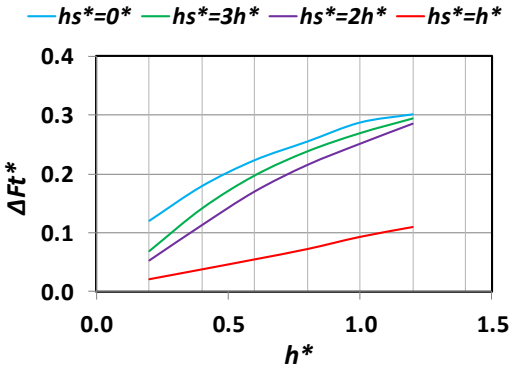

(b)

Figure 4: Magnitude of the reduction in (a) soil shear and (b) tip resistance

\section{Conclusion}

This study has been motivated by the need for further investigation to predict the effect of suction induced seepage on soil resistance to caisson installation in seabed profiles with low permeability layers. Firstly, the normalised model problem of suction induced seepage around a caisson foundation has been formulated considering the variation of the pressure gradient around the caisson wall. In order to investigate the effects on caisson installation, of the presence of a low permeability layer such as silt, four different soil profiles were considered. A semianalytical approach has been developed to calculate the reduction in soil resistance due to applied suction, in each of these soil profiles. The results revealed that the presence of a silt layer at a certain depth in homogenous sand, can affect the reduction in soil resistance to caisson penetration and reduces the benefits of suction induced seepage on caisson installation. Furthermore, the location of the silt layer plays an important role. It was observed that 
reduction in soil resistance due to suction induced seepage becomes significantly smaller when the caisson tip gets closer to the silt interface, compared to homogenous sand. Finally, this study suggests that the applied suction in seabed profiles where low permeability layers exist at various depths, should be increased by about $60 \%$ for the caisson installation in the vicinity of a silt layer to obtain reductions in soil resistance similar to those that can be achieved in homogenous sand. Implications of such an increase in suction on critical soil conditions, such as piping, must be considered for the installation process to be safe. This aspect will be presented in a future publication.

\section{References}

Allersma, HGB, Hogervorst, JR, Pimoulle, M, 2001. Centrifuge modelling of suction pile installation in layered soil by percussion method. Proc 21st Int. Conf. on Offshore Mechanics and Artic Engineering.

Byrne, B. W., Houlsby, G. T., Martin, C. \& Fish, P., 2002. Suction caisson foundations for offshore wind turbines. Wind Engineering, pp. 145-155.

Cotter, O., 2009. The installation of suction caisson foundations for offshore renewable energy structures, PhD thesis, Oxford University.

Harireche, O., Mehravar, M. \& Alani, M. A., 2013. Suction caisson installation in sand with isotropic permeability varying with depth. Applied Ocean Research, Volume 43, pp. 256-263.

Harireche, O., Mehravar, M. \& Alani, M. A., 2014.Soil conditions and bounds to suction during the installation of caisson foundations in sand. Ocean Engineering, Volume 88, pp. 164-173.

Houlsby, G. T. \& Byrne, B. W., 2005. Design procedures for installation of suction caissons in sand. Proceedings of the Institution of Civil Engineering (ICE), pp. 135-144.

Ibsen, L. B. \&Thilsted, C. L., 2010. Numerical study of piping limits for installation of large diameter buckets in layered sand. Proceedings of the 7th European Conference on Numerical Methods in Geotechnical Engineering.

Matusi, N. et al., 2002. Review of penetration resistance based on in situ monitoring. Cupertino, Calif, Proc., 12th Int. Offshore and Polar Engineering Conf.

Mehravar, M, Harireche, O, Alani, AM, 2017. Modelling the variation of suction pressure during caisson installation in sand using FLAC3D. Ships and Offshore Structures, 12(7), 893-899.

Mehravar, M., Harireche, O., Faramarzi, A. \& Dirar, S., 2017. Soil Condition and piping criteria during suction caisson installation in layered strata. Birmingham, Proceedings of the 25th UKACM conference on the Computational Mechanics .

Raines, R. D., Ugaz, O. \&Garnier, J., 2005. Centrifuge modelling of suction piles in clay. London, Proc., Int. Symp. Frontiers in Offshore Geotechnics.

Tran, N. T., Randolph, M. F. \& Airey, D. W., 2007. Installation of suction caissons in sand with silt layers.Journal of geotechnical and Geoenvironmental engineering, ASCE, 133(10), pp. 1183-1191. 